\title{
Integral Analysis of RCA of Irkutsk Region Companies
}

\author{
Evgeniy A. Filatov* \\ Irkutsk Scientific Center, Siberian branch of the Russian Academy of Sciences, Irkutsk 664033, \\ Russia
}

\begin{abstract}
The financial position of a company depends on its liquidity, or otherwise, on how soon the funds invested in the assets turn into real money. The growth of non-payments complicates the company's rhythmic activities (purchase of raw materials, payment of labor and other expenses generated from revenue) and leads to an increase in accounts receivable. At the same time, excessive diversion of funds to production stocks, work in progress, finished products, etc. leads to the deadening of resources and inefficient use of working capital. Successful solution of the problem of working capital optimization can significantly increase the financial stability of the company, refinance and repay the debt, and significantly facilitate debt restructuring. Therefore, effective management of the company's working capital is the key to increasing the turnover of property and sales volumes. It involves not only the search for and attraction of additional sources of financing, but also their rational placement in the current assets of the company. The article presents the author's model of analyzing the profitability of working capital. The article reveals the influence of factors affecting the profitability of working capital and author's methodical approach to his calculations (method \# 2 integral factor analysis, developed by Filatov E.A.). The article presents the author's analytical, systematic statistical analysis of key performance indicators reveal the influence to change the profitability of working capital of the companies in the Irkutsk region of the Russian Federation.
\end{abstract}

\section{Introduction}

Working capital is a mobile asset in cash or in the form of inventory, which can be converted into cash during a single production cycle [1].

The essence of the company's current assets (funds) is determined by their economic role, the need to ensure the reproduction process, which includes both the production process and the circulation process. Unlike fixed assets that repeatedly participate in the production process, working capital functions only in one production cycle and, regardless of the method of production consumption, completely transfers its value to the finished product.

Working capital is the basis of the company's business. If it is in excess, it means that the company is not developing fast enough, does not invest in new projects, resources do not work. If it is not enough, then the financial stability decreases, the profit falls. The optimal

* Corresponding author: johnru3000@rambler.ru 
amount of capital is constantly changing depending on the current market conditions, the strategy of the organization, and the configuration of the business.

The financial and economic situation of an economic entity largely depends on how effectively working capital is used and its circulation takes place. This requires more attention to the formation and improvement of the working capital management system and the justification of its direct impact on the efficiency of the company's functioning from the standpoint of its modern assessment [2-7].

\section{Research Questions}

The theoretical and methodological basis of the study was the works of domestic and foreign scientists and specialists in the field of working capital management, financial management, budgeting, analysis of financial and economic activities.

Questions and problems related to the study of the process of working capital functioning are reflected in the works of both domestic and foreign scientists and specialists in this field. Among the well-known authors who study the functioning of working capital, it should be noted the works of I. A. Blank, E. V. Vasina, G. E. Kobrinsky, V. M. Anosov, A. F. Ionova, N. N. Selezneva, I. M. Kichigina, A. N. Kochurko, Ya. S. Antonyuk, V. V. Kovalev, L. A. Chaldaeva, E. S. Stoyanova, S. A. Sirotkin, etc. The greatest contribution to the study of this problem in foreign science was made by A. Smith, D. Ricardo, K. Marx, J. S. Mill, S. Myers, and others.

The need to improve the process of managing the use of working capital, aimed at improving the efficiency of commercial organizations, determined the relevance of the research topic.

\section{Materials and methods}

Based on the methods of deterministic (functional) factor analysis developed by the author $[8,9]$, we estimate the degree of influence of three factors on the change in the return on current assets (RCA) of companies in the Irkutsk region of the Russian Federation.

The initial data for the alternative factor analysis of the RCA of companies in the Irkutsk region of the Russian Federation are presented in Table 1 based on the data of 4 statistical bulletins of Irkutskstat (1. Financial results of organizations. Volume 2-large and mediumsized organizations. 2017; 2. Financial results of organizations. Volume 3 -small businesses. 2017; 3. Financial results of organizations. Volume 2-large and medium-sized organizations. 2018; 4. Financial results of organizations. Volume 3-small businesses. 2018).

Table 1. Baseline data for the factor analysis.

\begin{tabular}{|l|l|c|c|c|c|}
\hline No. & \multicolumn{1}{|c|}{ Indicators } & $\begin{array}{c}\text { No. } \\
\text { factor's }\end{array}$ & $\begin{array}{c}\mathbf{2 0 1 7} \\
(\mathbf{0}) *\end{array}$ & $\begin{array}{c}\mathbf{2 0 1 8} \\
(\mathbf{I}) * *\end{array}$ & $\begin{array}{c}\text { Deviation } \\
(\Delta) * * *\end{array}$ \\
\hline 1 & $\boldsymbol{V}-$ Net revenue, billions rubles & & 2068.9 & 2305.8 & 236.9 \\
\hline 2 & $\boldsymbol{P}-$ Net profit, billions rubles & & 211.3 & 391.0 & 179.7 \\
\hline 3 & $\begin{array}{l}\boldsymbol{A}-\text { Asset value (average annual rate), } \\
\text { billions rubles }\end{array}$ & & 2749.5 & 2955.9 & 206.4 \\
\hline 4 & $\begin{array}{l}\boldsymbol{C A}-\text { Current assets (average annual } \\
\text { rate), billions rubles }\end{array}$ & & 1066.9 & 1108.4 & 41.5 \\
\hline 5 & $\boldsymbol{R C A}-$ Return on Current Assets (2/4) & & 0.198060 & 0.352764 & $\mathbf{0 . 1 5 4 7 0 4}$ \\
\hline
\end{tabular}




\begin{tabular}{|l|l|l|l|l|l|}
\hline 6 & $\begin{array}{l}\text { CICA }- \text { Capital Intensity of Current } \\
\text { Assets (3/4) }\end{array}$ & $\boldsymbol{F}_{\boldsymbol{1}}$ & 2.577069 & 2.666771 & 0.089702 \\
\hline 7 & AT - Asset Turnover (1/3) & $\boldsymbol{F}_{2}$ & 0.752446 & 0.780060 & 0.027614 \\
\hline 8 & ROS - Return On Sales (2/1) & $\boldsymbol{F}_{3}$ & 0.102140 & 0.169578 & 0.067438 \\
\hline
\end{tabular}

where: $* \mathbf{0}$ - past (basic) period (year), taken as reference base; ${ }^{* *} \mathbf{I}$ - reported (current) period (year); $* * * \Delta$ - change for the period, calculated as the difference between the fact and the plan $(\mathbf{I}-\mathbf{0})$.

The original formula derived by the author for the factor analysis of RCA will have the following form (formula 1):

$$
\boldsymbol{R C A}=\frac{\boldsymbol{A}}{C A} * \frac{V}{A} * \frac{P}{V}=C I C A * A T * R O S=F_{1} * F_{2} * F_{3}=\prod_{n=1}^{3} F_{n}
$$

The author's model of RCA consists of 3 factors:

F1 $_{1}$ CICA - Capital Intensity of Current Assets, calculated as the ratio of the value of assets $(\boldsymbol{A})$ to the size of current assets $(\boldsymbol{C A})$. This is one of the key indicators for working capital planning. The indicator of capital intensity is important for characterizing the pace of economic development.

$\mathbf{F}_{2}-\mathbf{A T}$ - Asset Turnover, characterizes the ratio of revenue $(\boldsymbol{V})$ to the average annual cost of capital (assets) $(\boldsymbol{A})$ of the organization. This indicator reflects the efficiency of the use of assets.

$\mathbf{F}_{3}-$ ROS - Return On Sales is calculated as the ratio of net profit $(\boldsymbol{P})$ to revenue (net) from all types of sales $(\boldsymbol{V})$. Return on sales is an indicator of the company's pricing policy and its ability to control costs [10-13].

The resulting indicator - RCA - return on working capital or Return on Current Assets is calculated as the ratio of net profit $(\boldsymbol{P})$ to the average annual value of current assets $(\boldsymbol{C A})$. This coefficient shows the profitability of current assets, that is, how much profit a unit of current assets brings. The financial position of any company is closely related to the state and efficiency of the use of working capital. By properly managing them, the company gains independence from external sources of financing and increases its liquidity. It is necessary to analyze the RCA in order to timely identify and eliminate problems of inventory management, accounts receivable, and products in warehouses [14].

Based on the data in Table 1, it can be seen that:

- the capital intensity of current assets of companies in the Irkutsk region in 2017 was $257.71 \%$, then in 2018 it was $266.68 \%$, an increase of $8.97 \%$;

- the turnover of assets of companies in the Irkutsk region in 2017 was $75.24 \%$, then in 2018 it was $78.00 \%$, an increase of $2.76 \%$;

- the return of sales of companies in the Irkutsk region in 2017 was $10.21 \%$, then in 2018 it was $16.95 \%$, an increase of $6.74 \%$.

The resulting indicator of the author's model of the RCA of companies in the Irkutsk region in 2017 was $19.81 \%$, then in 2018 it was $35.28 \%$, an increase of $\mathbf{1 5 . 4 7 \%}$.

The cumulative deviation of the resulting indicator $(\triangle \boldsymbol{R C A})$ is determined by the formula 2:

$$
\Delta R C A=\sum_{n=1}^{3} R C A\left(F_{n}\right)=\Delta R C A\left(F_{1}\right)+\Delta R C A\left(F_{2}\right)+\Delta R C A\left(F_{3}\right)
$$

Next, we will consider the method No. 2 of integral factor analysis, developed by Filatov E. A. 
To form the main part of the formula $\left(\mathbf{F} \mathbf{O}_{\mathbf{n}}\right)$, it is necessary to use the principle of selecting the factors disclosed in Table 2.

Table 2. Selection of factors for the main part of the formula $\left(\mathbf{F O}_{\mathbf{n}}\right)$ by the author's integral method

\begin{tabular}{|c|c|c|c|c|}
\hline $\begin{array}{c}\text { Under } \\
\text { influence \# } \\
\text { factors }\end{array}$ & \multicolumn{2}{|c|}{ First multiplier } & \multicolumn{2}{c|}{ Second multiplier } \\
\cline { 2 - 5 } & $\mathbf{0}$ & I & I & $\mathbf{0}$ \\
\hline $\mathbf{1}$ & 2 & 3 & 2 & 3 \\
\hline $\mathbf{2}$ & 1 & 3 & 1 & 3 \\
\hline $\mathbf{3}$ & 1 & 2 & 1 & 2 \\
\hline
\end{tabular}

where: $\mathbf{m}$ - the number of indicators in the main part of the formula (table 2); $\mathrm{m}$ is determined by formula 3 :

$$
\mathbf{m}=\mathbf{n} *(2 *(\mathbf{n}-1))
$$

The calculation of the influence of factors on the change in the resulting indicator in the author's integral method No. 2 is presented in formulas 4.1-4.3:

$$
\begin{aligned}
& \Delta \operatorname{RCA}\left(\mathbf{F}_{1}\right)=\left(\Delta \mathbf{F}_{1} \text { * FO№2 } 1\right)+\mathbf{Z} \text { №2 } \\
& \Delta \operatorname{RCA}\left(\mathbf{F}_{2}\right)=\left(\Delta \mathbf{F}_{2} \text { * FO№2 } 2\right)+\mathbf{Z} \text { №2 } \\
& \Delta \operatorname{RCA}\left(\mathbf{F}_{3}\right)=\left(\Delta \mathbf{F}_{3} \text { * FO№2 } 3\right)+\mathbf{Z} \text { №2 }
\end{aligned}
$$

When using the integral method, the additional increase in the resulting indicator («indecomposable remainder» $-\boldsymbol{Z}$ ), formed as a result of the interaction of factors, is distributed equally between them (formula 5).

$$
\text { ZNo2 }=\Delta \mathbf{R C A}-\sum\left(\left(\Delta \mathbf{F}_{\mathbf{n}} \text { * FO№2 }\right) / \mathbf{n}\right.
$$

where: $\mathbf{Z}$ - additional increase in the effective indicator due to the interaction of factors equally between them;

$\mathbf{F O}_{\mathbf{n}}$ - the main part of the formula of the author's integral method;

$\Delta \mathbf{F}_{\mathbf{n}}-$ deviation by a certain factor;

$\mathbf{n}-$ the number of factors involved in the analysis.

where: FO№2 $\mathbf{n}$ - the main part of the formula of the integral method is calculated according to formulas $6.1-6.3$ :

$$
\begin{aligned}
& \text { FO№2 } 2_{1}=\left(\left(\mathbf{F}_{2(0)} * \mathbf{F}_{3(\mathrm{I})}\right)+\left(\mathbf{F}_{2(\mathrm{I})} * \mathbf{F}_{3(0)}\right)\right) / 2 \\
& \text { FO№2 } 2=\left(\left(\mathbf{F}_{1(0)} * \mathbf{F}_{3(\mathrm{I})}\right)+\left(\mathbf{F}_{1(\mathrm{I})} * \mathbf{F}_{3(0)}\right)\right) / 2 \\
& \text { FO№2 } 2_{3}=\left(\left(\mathbf{F}_{1(0)} * \mathbf{F}_{2(\mathrm{I})}\right)+\left(\mathbf{F}_{1(\mathrm{I})} * \mathbf{F}_{2(0)}\right)\right) / 2
\end{aligned}
$$

To form the main part of the formula (FO№2 $\mathbf{n}$ ), it is necessary to use the principle of choice of factors disclosed in table 2.

The approbation of the author's method of factor integral analysis No. 2 presented above is presented in Tables No. 3, 4. 
Table 3. Components of the formula according to the author's integral method No. 2.

\begin{tabular}{|c|c|c|c|}
\hline \multirow{2}{*}{$\begin{array}{c}\text { № } \\
\text { formulae }\end{array}$} & \multicolumn{3}{|c|}{ Part of the formula } \\
\hline & $\Delta \mathbf{F}_{\mathbf{n}}$ & $\begin{array}{l}\text { The main part of the formula } \\
\text { (FO№2 } 2_{n} \text { ) }\end{array}$ & Z№2 \\
\hline 1 & $\Delta \operatorname{RCA}\left(\mathrm{F}_{1}\right)=\Delta \mathrm{F}_{1} *$ & $\begin{array}{l}\left(\left(\mathrm{F}_{2(0)} * \mathrm{~F}_{3(\mathrm{I})}\right)+\right. \\
\left.\left(\mathrm{F}_{2(\mathrm{I})} * \mathrm{~F}_{3(0)}\right)\right) / 2\end{array}$ & Z№2 \\
\hline 2 & $\Delta \operatorname{RCA}\left(\mathrm{F}_{2}\right)=\Delta \mathrm{F}_{2} *$ & $\begin{array}{l}\left(\left(\mathrm{F}_{1(0)} * \mathrm{~F}_{3(\mathrm{I})}\right)+\right. \\
\left.\left(\mathrm{F}_{1(\mathrm{I})} * \mathrm{~F}_{3(0)}\right)\right) / 2\end{array}$ & Z№2 \\
\hline 3 & $\Delta \mathrm{RCA}\left(\mathrm{F}_{3}\right)=\Delta \mathrm{F}_{3} *$ & $\begin{array}{l}\left(\left(\mathrm{F}_{1(0)} * \mathrm{~F}_{2(\mathrm{I})}\right)+\right. \\
\left.\left(\mathrm{F}_{1(\mathrm{I})} * \mathrm{~F}_{2(0)}\right)\right) / 2\end{array}$ & Z№2 \\
\hline
\end{tabular}

\section{Results}

The result of the author's integral method No. 2 is presented in Table 4.

Table 4. The result of the author's integral method No. 2.

\begin{tabular}{|c|l|c|c|c|}
\hline \multirow{2}{*}{\begin{tabular}{c}
\multirow{2}{*}{ № } \\
factor's
\end{tabular}} & \multicolumn{4}{|c|}{ Part of formula } \\
\cline { 2 - 5 } & $\Delta \mathbf{F}_{\mathbf{n}}$ & $\begin{array}{c}\text { Main part of } \\
\text { formula (FO№2 }\end{array}$ & ZNo2 & Final result \\
\hline 1 & $\begin{array}{l}\Delta \mathrm{RCA}\left(\mathrm{F}_{1}\right)= \\
0.089702\end{array}$ & 0.103637 & 0.000056 & 0.009352 \\
\hline 2 & $\begin{array}{l}\Delta \mathrm{RCA}\left(\mathrm{F}_{2}\right)= \\
0.027614\end{array}$ & 0.354699 & 0.000056 & 0.009850 \\
\hline 3 & $\begin{array}{l}\Delta \mathrm{RCA}\left(\mathrm{F}_{3}\right)= \\
0.067438\end{array}$ & 2.008434 & 0.000056 & 0.135501 \\
\hline Total & \multicolumn{2}{|c|}{0.154537} & 0.000167 & $\mathbf{0 . 1 5 4 7 0 4}$ \\
\hline
\end{tabular}

The final change in the RCA of companies in the Irkutsk region was positively influenced by:

- an increase in the capital intensity of current assets by $8.97 \%$, caused an increase in the studied indicator by $\mathbf{0 . 9 4 \%}$;

- an increase in the turnover of assets by $2.76 \%$, caused an increase in the studied indicator by $0.98 \%$;

- an increase in the return of sales by $6.74 \%$, caused an increase in the studied indicator by $13.55 \%$.

The combined impact of the three factors resulted in a $\mathbf{1 5 . 4 7 \%}$ increase in the RCA.

\section{Discussion}

A comparison of the results by the methods (traditional and author's) of factor analysis of changes in the RCA of companies in the Irkutsk region is presented in Table 5. 
Table 5. Comparison of results by factor analysis methods

\begin{tabular}{|c|l|c|c|c|}
\hline No. & $\Delta$ RCA $\left(\mathrm{F}_{n}\right)$ & $\begin{array}{c}\text { Result according } \\
\text { to traditional } \\
\text { methods }\end{array}$ & $\begin{array}{c}\text { The result of } \\
\text { the author's } \\
\text { integral } \\
\text { method No. 2 }\end{array}$ & $\Delta$ \\
\hline 1 & $\Delta$ RCA $\left(\mathrm{F}_{1}\right)=$ & 0.006894 & 0.009352 & 0.002458 \\
\hline 2 & $\Delta$ RCA $\left(\mathrm{F}_{2}\right)=$ & 0.007522 & 0.009850 & 0.002329 \\
\hline 3 & $\Delta \mathrm{RCA}\left(\mathrm{F}_{3}\right)=$ & 0.140288 & 0.135501 & -0.004787 \\
\hline & Total & $\mathbf{0 . 1 5 4 7 0 4}$ & $\mathbf{0 . 1 5 4 7 0 4}$ & $\mathbf{0 . 0 0 0 0 0 0}$ \\
\hline
\end{tabular}

The validity of the application of the integral method in economics is only conditional, since it requires the continuity of the function describing the factor relationship, and an infinitesimal change in features, which in economic phenomena often cannot be in principle, since many indicators change discretely.

\section{Conclusion}

The significant amount of working capital involved in the operational process, the variety of types and specific types of assets formed at the expense of this capital, its determining role in accelerating the turnover of total capital and ensuring constant solvency, as well as a number of other conditions determine the complexity of the tasks associated with managing the use of this type of capital.

Given the significant amount of financial resources invested in the company's current assets, the diversity of these resources, as well as the role of current assets in the formation of the company's solvency, the development of a working capital management system and a mechanism for implementing the decisions made is one of the priority tasks of financial management [15].

The article is carried out within the framework of the scientific project of the Siberian Branch of the Russian Academy of Sciences «Socio-economic development of the resource region in the context of changing external factors (on the example of the Irkutsk region)».

\section{References}

1. E.M. Rogova, E.A. Tkachenko, Financial management, Moscow: Yurayt, 2011, 540 p. (In Russian).

2. V.I. Barilenko, Complex economic analysis of economic activity, Moscow: Yurayt, 2020, 456 p. (In Russian).

3. I.V. Kosorukova, Analysis of financial and economic activity, Moscow: KnoRus, 2021, 456 p. (In Russian).

4. E.V. Nikiforova, Complex strategic analysis of sustainable development of economic entities, Moscow: KnoRus, 2019, 168 p. (In Russian).

5. N.S. Plaskova, Economic analysis, Moscow: Eksmo, 2009, 703 p. (In Russian).

6. S.M. Pyastolov, Economic analysis of the company, Moscow: Academic project, 2010, 576 p. (In Russian).

7. G.V. Shadrina, Economic analysis, Moscow: Yurayt, 2019, 432 p. (In Russian).

8. E.A. Filatov, Integral factor analysis of financial profitability by Filatov's method. The European Proceedings of Social \& Behavioural Sciences, Volume L - RPTSS; No: 44, 
2018, pp. 356-363. DOI: https://dx.doi.org/10.15405/epsbs.2018.12.44

9. E.A. Filatov, Author's integrated methods of analysis of the model of return on assets of construction companies. IOP Conf. Series: Materials Science and Engineering, Number 1, Volume 667, 2019, 012024. DOI: 10.1088/1757-899X/667/1/012024

10. D. Young, Economic value added: A primer for European managers. European Management Journal, Vol. 15, № 4, 1997, pp. 335-344.

11. P.G. Farnham, Economics for managers, Prentice Hall, 2005, 558 p.

12. E.G. Dolan, D.E. Lindsey, Economics, The Dryden Press, 1988, 921 p.

13. J. Naylor Management, Prentice Hall, 2004, 668 p.

14. C.W.L. Hill, G.R. Jones, Strategic management. An Integrated approach, Houghton Mifflin Company, 2004, $1182 \mathrm{p}$.

15. N.N. Kursov, Management of working capital use as a tool for improving the efficiency of industrial enterprises: Dissertation of candidate of economic science, Samara, Samara State University of Economics, 2006, 216 p. (In Russian) 